\title{
Could protein tertiary structure influence mammary transgene expression more than tissue specific codon usage?
}

\author{
Zuyong He $\cdot$ Yiqiang Zhao $\cdot$ Gui Mei \\ Ning Li $\cdot$ Yaosheng Chen
}

Received: 11 August 2009/Accepted: 19 May 2010/Published online: 19 June 2010

(C) The Author(s) 2010. This article is published with open access at Springerlink.com

\begin{abstract}
Animal mammary glands have been successfully employed to produce therapeutic recombinant human proteins. However, considerable variation in animal mammary transgene expression efficiency has been reported. We now consider whether aspects of codon usage and/or protein tertiary structure underlie this variation in mammary transgene expression.
\end{abstract}

Keywords Transgenic animal bioreactor - Codon usage $\cdot$ Mammary gland $\cdot$ Tertiary structure

Zuyong He and Yiqiang Zhao contribute equally to this work.

Electronic supplementary material The online version of this article (doi:10.1007/s11248-010-9411-8) contains supplementary material, which is available to authorized users.

Z. He $\cdot$ Y. Chen $(\bowtie)$

State Key Laboratory of Biocontrol, School of Life Sciences, Sun Yat-Sen University, 510006 Guangzhou, People's Republic of China

e-mail: chyaosh@mail.sysu.edu.cn

Y. Zhao

Buck Institute for Age Research, California, USA

G. Mei

Institute of Animal Sciences, Guangdong Academy of Agricultural Sciences, 510640 Guangzhou, People's Republic of China

N. Li

State Key Laboratory for Agrobiotechnology, China Agricultural University, 100193 Beijing, People's

Republic of China

\section{Introduction}

The expression of functional proteins in heterologous hosts is a cornerstone of modern biopharming. However, many human proteins are often difficult to express in unicellular organisms such as bacterium and yeast. The underlying problem is that codon bias has a profound impact on the heterologous expression of human proteins in these organisms. Codon usage has been found to be the single most important factor in prokaryotic gene expression. Therefore laborious and time consuming codon optimization is often necessary to achieve a successful expression in unicellular organisms (Gustafsson et al. 2004). Contrary to unicellular organisms, no obvious codon bias has been observed among human and several other mammals in previous studies. Thus animal mammary gland is considered an ideal bioreactor for producing functional human proteins without codon optimization. With this concept in mind, a number of transgenic livestock have been created to produce different recombinant human proteins in their milk, and in 2006 a recombinant human protein purified from a transgenic goat was approved for clinical use in Europe by the European Medicine Agency (Houdebine 2009).

However, considerable variation in expression efficiency has been found in the heterologuous expressions of human proteins in the milk of transgenic animals produced in our lab and other groups. Generally a number of proteins such as serpin peptidase inhibitors and immunoglobulins which are abundant in human tissues other than mammary gland tend to exhibit a 
higher expression level in transgenic milk, while many other human proteins such as interleukin-2, coagulation factor 8 and catalase are difficult to express in milk (Wright et al. 1991; Tang et al. 2008; Buhler et al. 1990; Niemann et al. 1999; He et al. 2008a, b). These examples cause us to question whether tissue specific codon usage pattern affects translational regulation during the heterologuous expression of human proteins in animal mammary gland?

Recently several independent studies concluded that codon bias might be a factor involved in translation regulation in humans. One study concluded that genes selectively expressed in one human tissue can often be discriminated from genes expressed in another tissue on the basis of their synonymous codon usage (Plotkin et al. 2004) while another study reported that the amount of tRNA varies widely among different human tissues based on microarray results, further more they showed that the relative tRNA abundance significantly correlates with codon usage of tissue specific genes (Dittmar et al. 2006). The effective number of codons (ENC) is a most common index for measurement of codon bias. ENC is analogous to the effective number of alleles in population genetics. However, ENC can not reveal which codons are more frequent than others but rather indicates the overall departure from random synonymous codon choice. As a result, two genes may exhibit the same degree of overall bias, but differ dramatically in their particular choice of synonymous codons. Thus in this study, we used a two-tailed Fisher exact test to measure the distance of synonymous codon usage between two genes (Plotkin et al. 2004). Unlike metrics such as "relative synonymous codon usage', which are noisy when applied to individual genes, the Fisher exact test for small sample sizes based codon usage measure can be applied to genes that contain only a few examples of each amino acid.

We propose two scenarios: first, the different expression levels of recombinant human proteins in the milk of transgenic animals is due to the variation in synonymous codon usage patterns between mammary gland and other human tissues; or, second, protein tertiary structure may influence mammary transgene expression.

Human and mouse tissue specific codon usage

We have made pair-wise comparisons of codon usage among seven human tissues. When comparing heart to kidney (Fig. 1), virtually all kidney associated genes are clustered in a separate middle clade from the heart associated genes. The observed separation between these two classes of genes would not have occurred by random chance $(P<0.001)$. The observed clustering is the result of systematic differential codon usage between heart and kidney specific genes. Fig. 1 indicates that we can generally discriminate between heart and kidney expressed genes on the basis of their codon usage alone. Similarly, kidney specific genes can be discriminated from lung and pancreas specific genes (supplementary Fig. 1). However, many pairs of tissue specific gene sets do not exhibit significantly different codon usage patterns (e.g., brain versus pancreas, $P=0.384$; supplementary Fig. 2). Unexpectedly, in the tested six mouse tissues, we can not observe any pair of tissues that can be separated from each other on the basis of their codon usage with a statistical significant test. Only heart specific genes can be nearly discriminated from liver specific genes $(P=0.072$; supplementary Fig. 3).

When comparing human mammary gland to six other tissues, only heart, lung and pancreas specific genes can be discriminated from mammary gland specific genes on the basis of codon usage (heart versus mammary gland, $P<0.001$; lung versus mammary gland, $P=0.002$; pancreas versus mammary gland, $P<0.001$; supplementary Fig. 4 ), and the other three tissues in the test can not be distinguished from mammary gland (brain versus mammary gland, $P=0.368$; kidney versus mammary gland, $P=0.368$; liver versus mammary gland, $P=0.536$; supplementary Fig. 5). In the tested six mouse tissues, only genes selectively expressed in heart and pancreas can be distinguished from mouse mammary gland specific genes (heart versus mammary gland, $P=0.002$; pancreas versus mammary gland, $P=0.038$; supplementary Fig. 6). Thus there does appear to be codon usage differences between mammalian tissues.

Does expression levels of recombinant human proteins in transgenic milk correlate with mammary gland specific codon usage?

Successful examples of expressing recombinant human proteins in transgenic animals to date are summarized in Table 1 and the greatest expression 
Fig. 1 A dendogram reflecting the codon usage of 22 genes selectively expressed in heart (red) and 17 genes selectively expressed in human kidney (black). The pairwise distances underlying this tree reflect the degree to which the genes differ in their codon usage. As this tree demonstrates, heartspecific genes can generally be distinguished from heartspeicific genes purely on the basis of their synonymous codon usage. The observed separation between these two classes of genes would not have occurred by random chance $(P<0.001)$

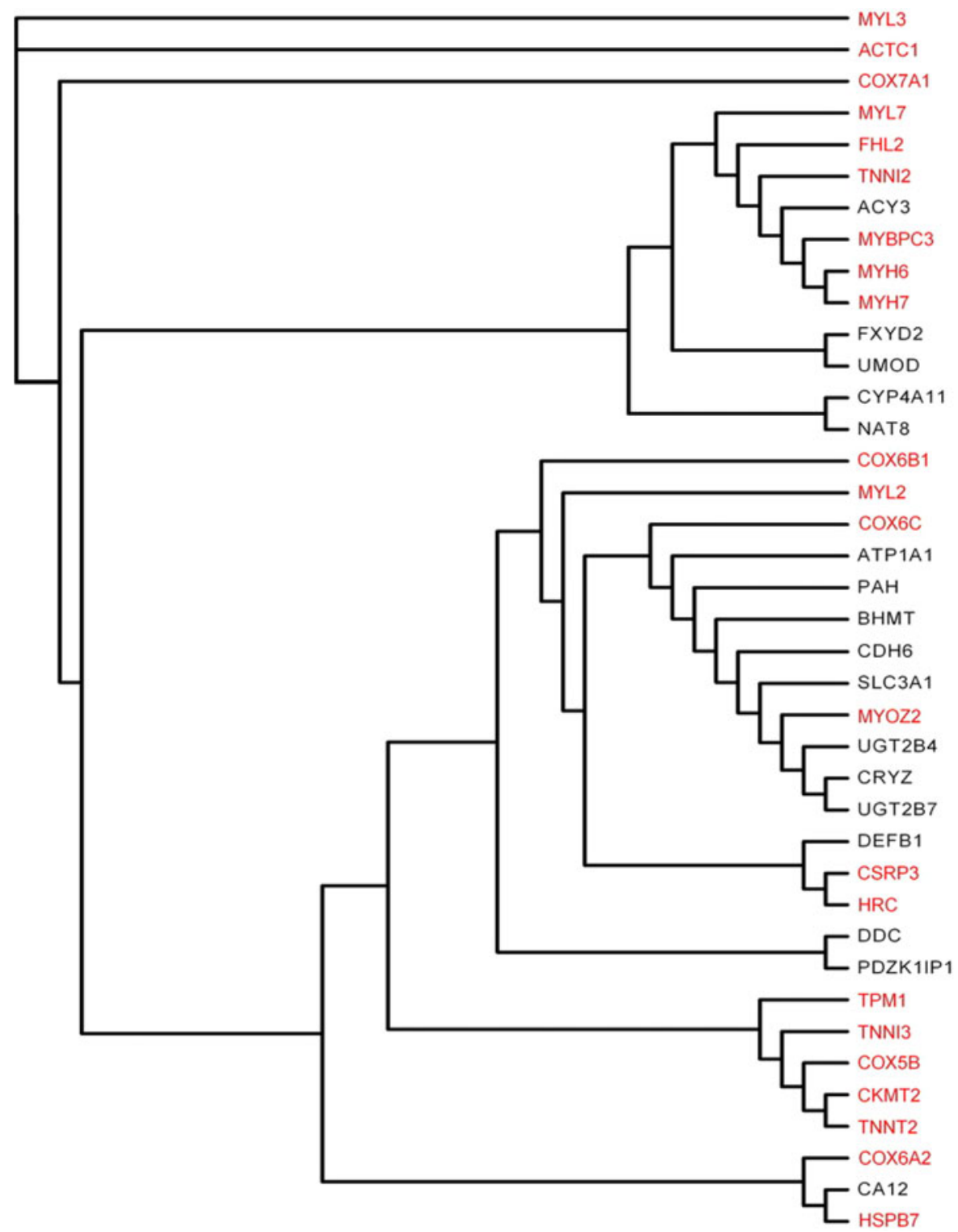

clustered close to most human mammary gland specific genes and milk proteins. The observed three classes of genes can not be discriminated from each other (mammary gland, $P=0.574$; milk proteins, $P=0.900$; supplementary Fig. 7). Similar results can be observed in the comparing of recombinant proteins to mouse mammary gland specific genes and milk proteins (mammary gland, $P=0.952$; milk proteins, $P=0.974$; supplementary Fig. 8 ). Further comparing codon usage of milk proteins among 19 different mammals showed that most milk proteins were prone to use similar codon usage patterns FIX and those less efficiently expressed recombinan proteins (LYZ, CAT, IL2 and mCol18a1) were 


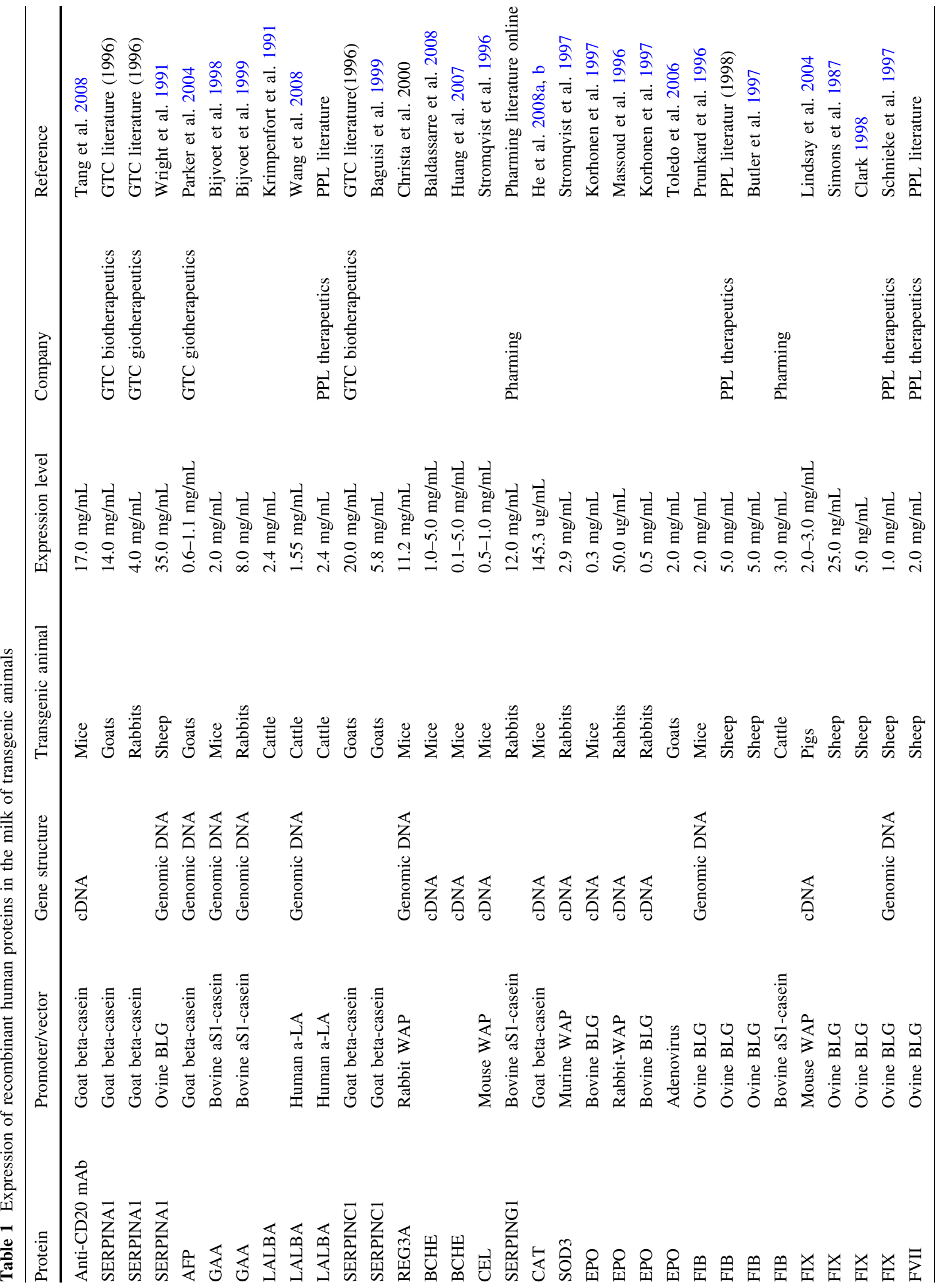




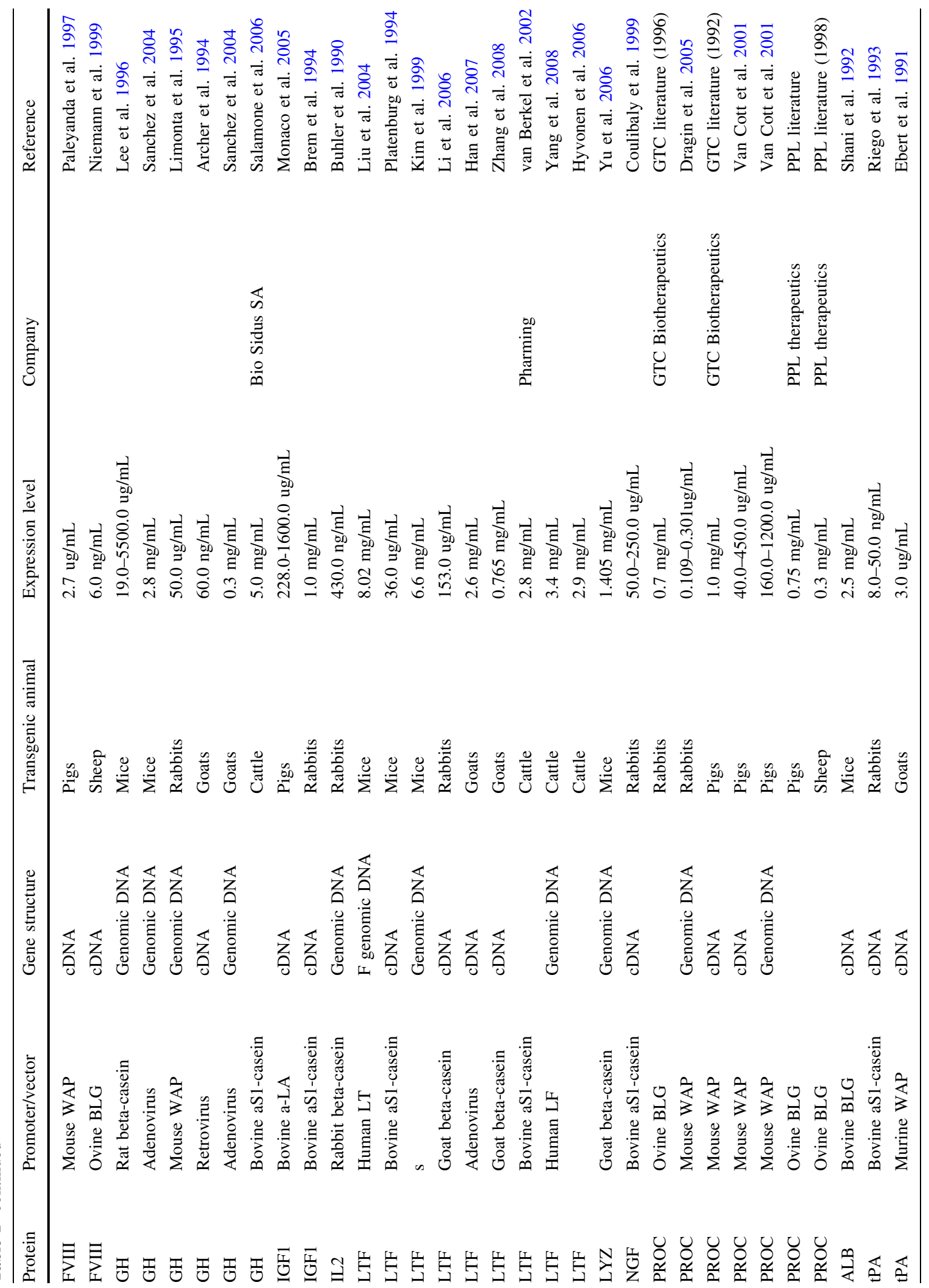


among different mammalian species (supplementary Fig. 9). Thus we compared the codon usage of recombinant proteins to milk proteins in the main five livestock cow, sheep, goat, rabbit and pig. In each animal, except for certain proteins, the cluster result was quite similar to human and mouse (Fig. 3). Thus we dismiss our proposal that expression levels of recombinant human proteins in the milk of transgenic animals correlate with mammary gland specific codon usage patterns.

Recombinant human proteins with greater expression levels in transgenic milk share similar protein domains with milk proteins

The main domains of recombinant proteins expressed in the milk of transgenic animals and mammalian milk proteins derived from CATH were summarized in Table 2. Casein makes up the main component of milk proteins, as in bovine milk, it reaches as great as $82 \%$ of the total milk proteins (Jensen 1995). When we investigated the main domains of the main four caseins [casein alpha S1 (CSN1S1), casein alpha S2 (CSN1S2), casein beta (CSN2), and casein kappa (CSN3)], it can be observed that all four caseins share a similar alpha-beta based major domain (Fig. 4). With the exception of CSN1S2 which is composed of an alpha-beta barrel domain, the other three caseins all are composed of a 3-layer (aba) sandwich shaped major domain. Interestingly we found that within the top 13 high level expressed recombinant proteins in the milk of transgenic animals (expression level $\geqq 5 \mathrm{mg} / \mathrm{mL}$ ), 10 proteins share a similar alpha-beta based major domain with casein proteins, especially those with extra-higher expression levels such as SERPINA1, SERPINC1, SERPING1, REG3A, LTF and BCHE which all possess a 2-layer or 3-layer (aba) sandwich shaped major domain similar to the most abundant milk proteins CSN1S1, CSN2 and CSN3. Beside the 10 high level expressed proteins, there are another two proteins CEL $(1.00 \mathrm{mg} / \mathrm{mL})$ and Calc1 $(2.10 \mathrm{mg} / \mathrm{mL})$ each has a CSN2 like 3-layer (aba) sandwich domain and mainly alpha beta domain, respectively, though these two recombinant proteins do not get an extra-higher expression levels in the transgenic milk. However, the moderate expression levels are probably due to their cDNA based expression constructs. Because the gene structure used in an expression construct seems to have 


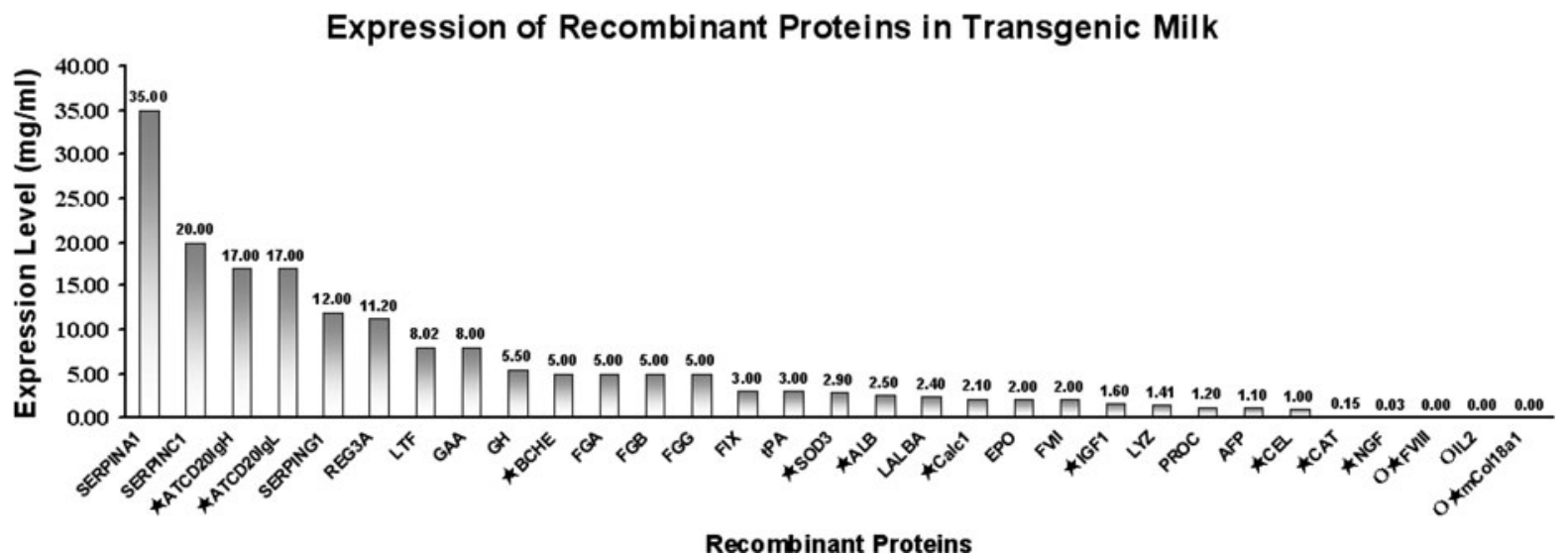

Fig. 2 Expression levels of recombinant human proteins in the milk of transgenic animals. The expression level of each protein presents the highest one among different studies summarized in Table 1; ATCD20 IgH and ATCD20 IgL indicate the heavy and light chain of human anti-CD20 monoclonal antibody; FGA, FGB and FGG note the alpha chain, beta chain and gamma chain of fibrinogen (FIB)

significant impact on expression level, generally a genomic DNA sequence results in several orders of magnitude greater expression level than a cDNA sequence (Whitelaw et al. 1991).

Promoter plays a critical role at transcriptional regulation of transgene expression. Milk protein gene promoters must be used when expressing recombinant proteins in animal mammary gland. Promoters derived from $\kappa$-casein and $\alpha \mathrm{S} 2$-casein are particularly weak (Houdebine 2000). In Table 1, none of the reported studies used these two kinds of promoter. Bovine $\alpha$ S1-casein, goat $\beta$-casein, mouse murine acidic protein, and ovine $\beta$-lactoglobulin derived promoters were most popularly used in these studies. Under the regulation of ovine $\beta$-lactoglobulin promoter and using genomic DNA of the foreign gene, transgenic sheep expressed high level of SERPINA1 $(35 \mathrm{mg} / \mathrm{mL})$ and FIB $(5 \mathrm{mg} / \mathrm{mL})$ which both possessing major domains similar to caseins, whereas lower level of FIX $(1 \mathrm{mg} / \mathrm{mL})$ which has a major domain distinct with caseins. Similarly, under the control of goat beta-casein promoter, transgenic goats expressed high levels of SERPINC1 $(20 \mathrm{mg} / \mathrm{mL})$ and SERPINA1 $(14 \mathrm{mg} / \mathrm{mL})$, whereas lower levels of AFP $(1.1 \mathrm{mg} / \mathrm{mL})$ and tPA $(3 \mathrm{mg} / \mathrm{mL})$;furthermore, under the control of bovine $\alpha \mathrm{S} 2$-casein, transgenic rabbits expressed high levels of SERPING1 (12 mg/ $\mathrm{mL})$ and GAA $(8 \mathrm{mg} / \mathrm{mL})$, whereas lower levels of respectively; mCol18a1 stands for mouse collagen, type XVIII, alpha 1; star notes the expression level of recombinant protein with a cDNA based expression construct; open circle indicates the expression level values of hFVIII $(0.0027 \mathrm{mg} / \mathrm{mL})$, hIL$2(0.000043 \mathrm{mg} / \mathrm{mL})$ and $\mathrm{mCol} 18 \mathrm{a} 1(0.00003 \mathrm{mg} / \mathrm{mL})$ which all are too low to be fully presented on the top of the bar

tPA $(0.05 \mathrm{mg} / \mathrm{mL}), \quad \mathrm{NGF}(0.25 \mathrm{mg} / \mathrm{mL})$ and IGF1 $(1 \mathrm{mg} / \mathrm{mL})$. These cases may indicate protein structure appears to be an important factor affecting the expression level of transgene in the mammary gland. Taken together, we suggest that those recombinant proteins share similar major domains to casein proteins may have potential to achieve a greater expression level in the milk of transgenic animals when they are under similar transcriptional regulation.

\section{Materials and methods}

Gene sequences analysis

Coding sequences of genes in this study were obtained from GenBank. On the basis of BioGPS (http://biogps.gnf.org/\#goto=welcome) and several other extensive mRNA expression microarray studies (Warrington et al. 2000; Hsiao et al. 2001; Liang et al. 2006; Shyamsundar et al. 2005; SaitoHisaminato et al. 2002), we have identified genes which are selectively expressed in human and mouse mammary gland at lactation stage and in six other tissues: human [mammary gland (13 genes), brain (25 genes), heart (22 genes), kidney (17 genes), liver (26 genes), lung (19 genes) and 

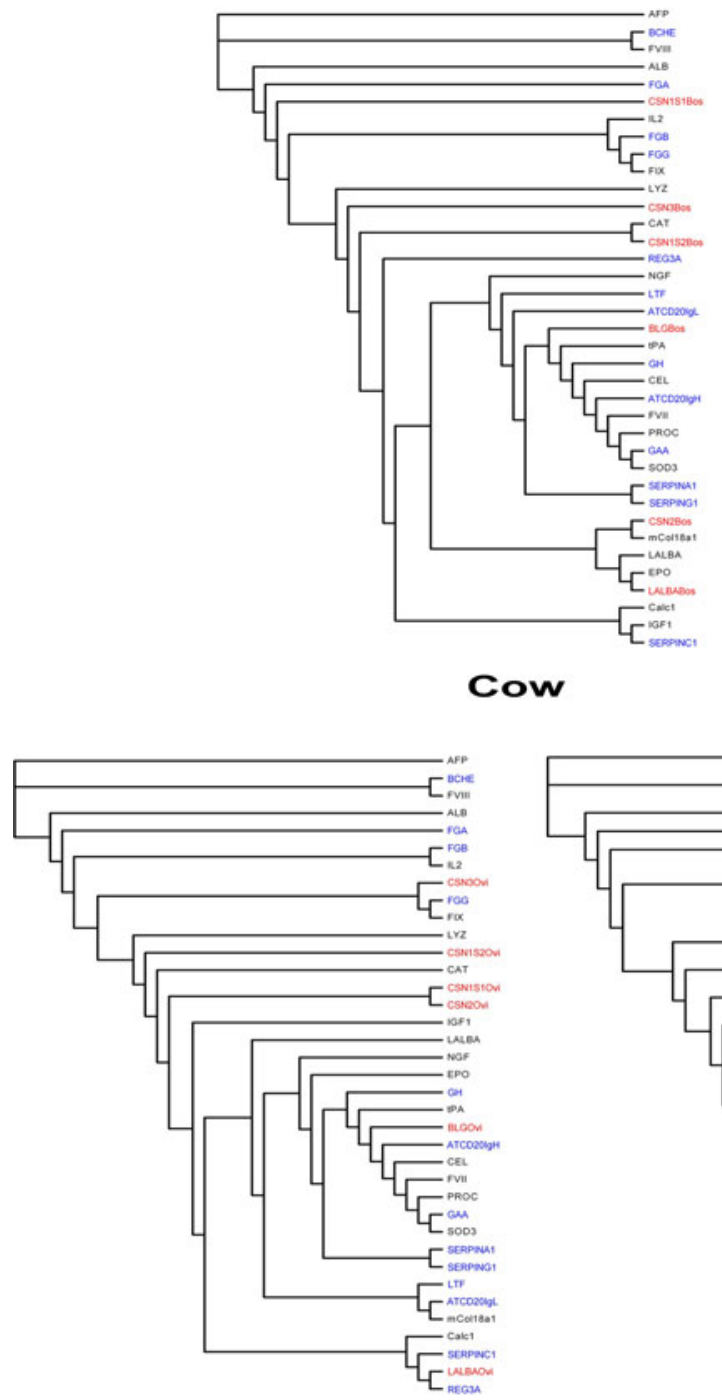

Sheep

Fig. 3 Dendograms reflecting the codon usage of milk proteins of the main five livestock (red) and recombinant proteins. The top 13 high level expressed recombinant proteins $(\geqq 5 \mathrm{mg} / \mathrm{mL}$ ) are showed in blue, and moderate and lower expressed recombinant proteins are indicated in black. The

pancreas (27 genes; S1)] and mouse [mammary gland (15 genes), brain (24 genes), heart (22 genes), kidney (13 genes), liver (24 genes), lung (17 genes) and pancreas (21 genes; S2)].

The sequences of animal milk protein genes and recombinant proteins were summarized in supporting materials Table S3 and Table S4 respectively.

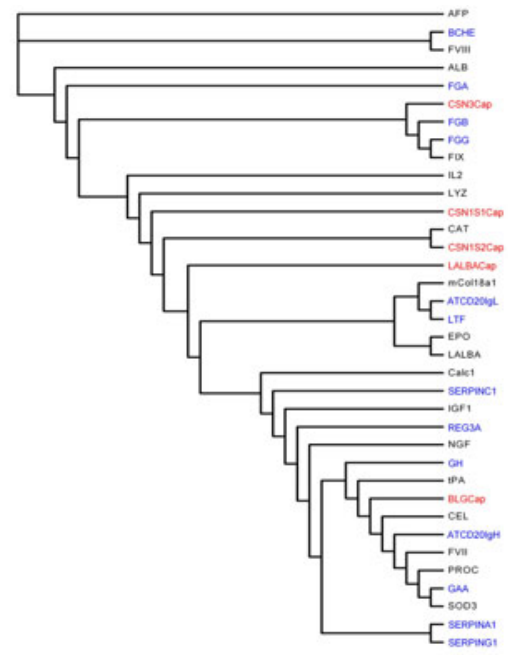

Goat

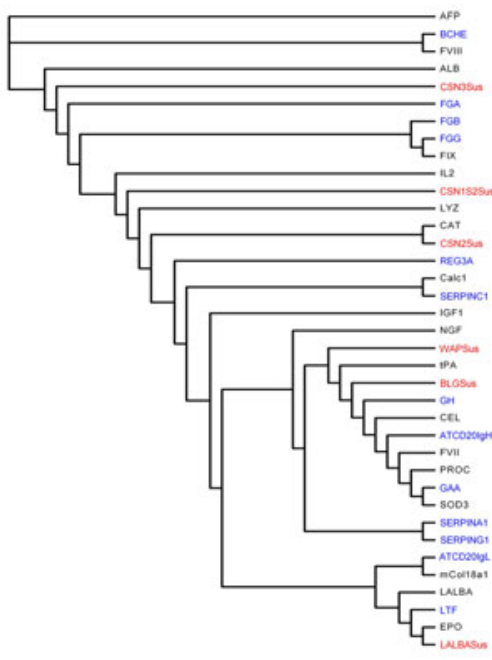

Pig
Rabbit three classes of genes (indicated in three different colour) can not be clearly discriminated from each other (cow, $P=0.992$; goat, $P=0.982$; sheep, $P=0.992$; rabbit, $P=0.962$; pig, $P=0.994)$

\section{Codon usage analysis}

For this study, the distance of synonymous codon usage between two genes were measured based on a two-tailed Fisher exact test method (Plotkin et al. 2004). Briefly, degree of codon bias in common sense as the departure from random synonymous codon choice is not concerned, but rather the degree to 
Table 2 The main domains of recombinant proteins expressed in transgenic milk

\begin{tabular}{|c|c|c|}
\hline Protein & CATH Code & Domain \\
\hline IGF1 & 1.10 .100 .10 & Mainly alpha; orthogonal bundle; insulin-like, subunit E; insulin-like, subunit E \\
\hline AFP & 1.10.246.10 & Mainly alpha; orthogonal bundle; serum albumin; chain A, dDomain 1 \\
\hline ALB & 1.10.246.10 & Mainly alpha; orthogonal bundle; serum albumin; chain A, domain 1 \\
\hline$L A L B A$ & 1.10 .530 .10 & Mainly alpha; orthogonal bundle; lysozyme \\
\hline LYZ & 1.10 .530 .10 & Mainly alpha; orthogonal bundle; lysozyme \\
\hline EPO & 1.20 .1250 .10 & Mainly alpha; up-down bundle; growth hormone; chain: A; \\
\hline $\mathrm{GH}^{\mathrm{a}}$ & 1.20 .1250 .10 & Mainly alpha; up-down bundle; growth hormone; chain A \\
\hline IL2 & 1.20 .1250 .10 & Mainly alpha; up-down bundle; growth hormone; chain A \\
\hline NGF & 2.10 .90 .10 & Mainly beta; ribbon; cystine knot cytokines, subunit B; cystine-knot cytokines \\
\hline FIX & 2.40 .10 .10 & Mainly beta; beta barrel; thrombin, subunit $\mathrm{H}$; trypsin-like serine proteases \\
\hline FVII & 2.40 .10 .10 & Mainly beta; beta barrel; thrombin, subunit $\mathrm{H}$; trypsin-like serine proteases \\
\hline FVIII & 2.40 .10 .10 & Mainly beta; beta barrel; thrombin, subunit $\mathrm{H}$; trypsin-like serine proteases \\
\hline PROC & 2.40 .10 .10 & Mainly beta; beta barrel; thrombin, subunit $\mathrm{H}$; trypsin-like serine proteases \\
\hline tPA & 2.40 .10 .10 & Mainly beta; beta barrel; thrombin, subunit $\mathrm{H}$; trypsin-like serine proteases \\
\hline$B L G$ & 2.40 .128 .20 & Mainly beta; beta barrel; lipocalin \\
\hline CAT & 2.40 .180 .10 & Mainly beta; beta barrel; catalase HpII, chain A, domain 1 \\
\hline ATCD20IgH ${ }^{\mathrm{a}}$ & 2.60.40.10 & Mainly beta; sandwich; immunoglobulin-like; immunoglobulins \\
\hline ATCD21IgL & 2.60.40.10 & Mainly beta; sandwich; immunoglobulin-like; immunoglobulins \\
\hline SOD3 & 2.60.40.200 & Mainly beta; sandwich; immunoglobulin-like \\
\hline $\mathrm{mCol} 18 \mathrm{a} 1^{\mathrm{b}}$ & 3.10 .100 .10 & Alpha beta; roll; mannose-binding protein A, chain A; mannose-binding protein A, subunit A \\
\hline REG3A $A^{a, b}$ & 3.10 .100 .10 & Alpha beta; roll; mannose-binding protein A, Chain A; mannose-binding protein A, subunit A \\
\hline CSN1S2 & 3.20 .20 .70 & Alpha beta; alpha-beta barrel; TIM Barrel; aldolase class I \\
\hline $\mathrm{GAA}^{\mathrm{a}, \mathrm{b}}$ & 3.20 .20 .80 & Alpha beta; alpha-beta barrel; TIM barrel; glycosidases \\
\hline SERPINA $1^{\mathrm{a}, \mathrm{b}}$ & 3.30.497.10 & Alpha beta; 2-layer sandwich; antithrombin; chain I, domain 2; antithrombin, subunit I, domain 2 \\
\hline SERPINC1 $1^{\mathrm{a}, \mathrm{b}}$ & 3.30.497.10 & Alpha beta; 2-layer sandwich; antithrombin; chain I, domain 2; antithrombin, subunit I, domain 2 \\
\hline SERPING $1^{\mathrm{a}, \mathrm{b}}$ & 3.30 .497 .10 & Alpha beta; 2-layer sandwich; antithrombin; chain I, domain 2; antithrombin, subunit I, domain 2 \\
\hline $\mathrm{LTF}^{\mathrm{a}, \mathrm{b}}$ & 3.40 .190 .10 & $\begin{array}{l}\text { Alpha beta; 3-layer(aba) sandwich; D-maltodextrin-binding protein; domain 2; periplasmic binding } \\
\text { protein-like II }\end{array}$ \\
\hline CSN2 & 3.40 .50 .10150 & Alpha Beta; 3-Layer(aba) Sandwich; Rossmann fold; Diol Dehydratase; Chain B \\
\hline $\mathrm{BCHE}^{\mathrm{a}, \mathrm{b}}$ & 3.40 .50 .1820 & Alpha beta; 3-layer(aba) sandwich; rossmann fold \\
\hline $\mathrm{CEL}^{\mathrm{b}, \mathrm{c}}$ & 3.40 .50 .1820 & Alpha beta; 3-layer(aba) sandwich; rossmann fold \\
\hline CSN1S1 & 3.40 .630 .10 & Alpha beta; 3-layer(aba) sandwich; aminopeptidase; Zn peptidases \\
\hline CSN3 & 3.40 .710 .10 & Alpha beta; 3-layer(aba) sandwich; beta-lactamase; DD-peptidase/beta-lactamase superfamily \\
\hline $\mathrm{FGA}^{\mathrm{a}, \mathrm{b}}$ & 3.90 .215 .10 & Alpha beta; alpha-beta complex; gamma fibrinogen; chain A, domain 1 \\
\hline $\mathrm{FGB}^{\mathrm{a}, \mathrm{b}}$ & 3.90 .215 .10 & Alpha beta; alpha-beta complex; gamma fibrinogen; chain A, domain 1 \\
\hline $\mathrm{FGG}^{\mathrm{a}, \mathrm{b}}$ & 3.90.215.10 & Alpha beta; alpha-beta complex; gamma fibrinogen; chain A, domain 1 \\
\hline Calc1 $1^{\text {b,c }}$ & 3.90 .320 .20 & Alpha beta; alpha-beta complex; lambda exonuclease; chain A \\
\hline$W A P$ & 4.10 .75 .10 & Few secondary structures; irregular; R-elafin; R-elafin \\
\hline
\end{tabular}

The italic bold words note milk proteins

a The top 13 high level expressed recombinant proteins in the milk of transgenic animals (expression level $\geqq 5 \mathrm{mg} / \mathrm{mL}$ )

b The 13 recombinant proteins share similar domains with casein proteins

c The expression level was based on a cDNA construct 
Fig. 4 The tertiary structures of the main domains of casein proteins, 10 recombinant human proteins highly expressed in the milk of transgenic animal, and two moderately expressed proteins CEL $(1.00 \mathrm{mg} / \mathrm{mL})$ and Calc1 $(2.10 \mathrm{mg} / \mathrm{mL})$ based on cDNA expression constructs. Figures were made using VMD (http://www.ks.uiuc.edu/ Research/vmd/) and rendered using Snapshot
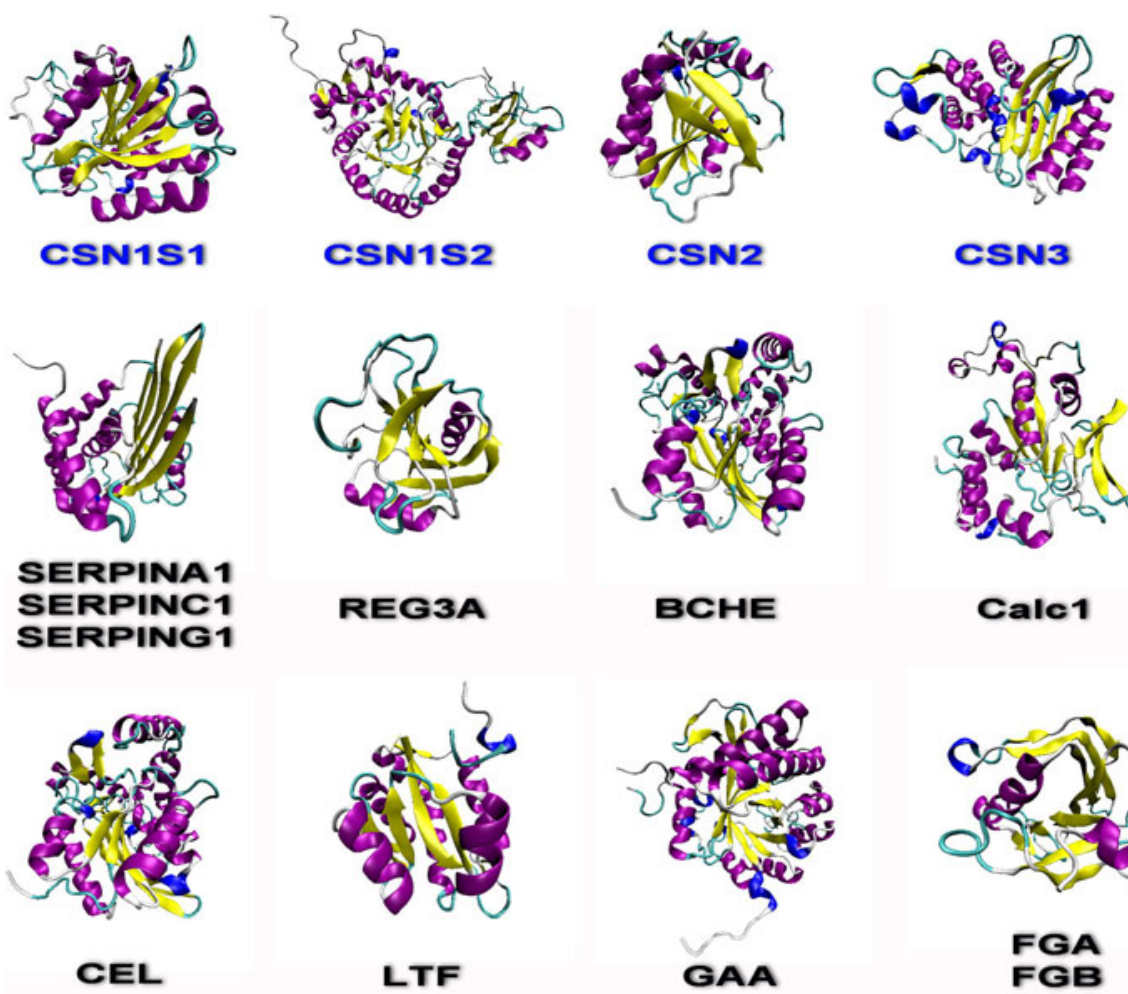

BCHE

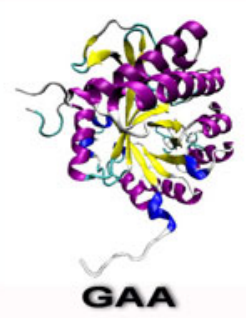

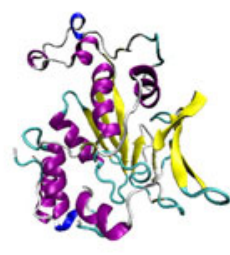

Calc1

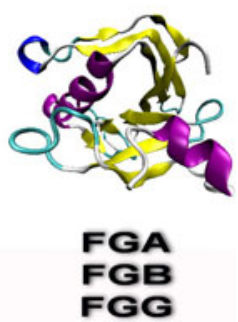

which genes differ in their encoding of amino acids is concerned. Given the coding sequences for a pair of genes, absolute frequency of each codon in each gene is first tabulated with condonW (http://codonw.source forge.net//). For each amino acid, a two-tailed Fisher exact test on the $n \times 2$ contingency table given by the frequencies of the amino acid's synonymous codons is calculated (e.g., for Ser $n=4$ : TCA, TCC, TCG, and TCT). As a result, for each amino acid a Pvalue indicating whether or not the genes use significantly different codons to encode that amino acid is obtained. For example, when comparing human brain ( 25 genes) to heart (22 genes), distance between codon usage of every pair of genes (including pairs from the same tissue) is calculated, thus obtaining a 47-by-47 symmetric matrix of pairwise distances. Distance between two genes is given by the number of amino acids that exhibit significantly different $(P<0.01)$ codon usage, as defined above (detailed SAS program was presented in supplementary materials S5). Then by using the neighbor joining method (PHYLIP v3.66; http://evolution.gs.washington.edu/ phylip.html), a dendogram that graphically represents the measured pairwise distances between the codon usage in the study genes can be produced. To test whether observed clustering of genes in a dendogram is nonrandom, $P$ value is calculated by comparing the observed summed distances along the tree between genes of the same tissue against a null distribution produced by randomly permuting the labels of the leaves.

Protein main domain analysis

Domains of recombinant proteins expressed in the milk of transgenic animals and mammalian milk proteins were evaluated with CATH (http://www. cathdb.info/) which is a hierarchical classification of protein domain structures based on clustering proteins at four major levels: Class (C), Architecture (A), Topology (T) and Homologous superfamily (H). Class is determined according to the secondary structure composition and packing within the structure. Three major classes are recognized; mainlyalpha, mainly-beta and alpha-beta. Architecture describes the overall shape of the domain structure as determined by the orientations of the secondary structures but ignores the connectivity between the 
secondary structures. It is currently assigned manually using a simple description of the secondary structure arrangement e.g. barrel or 3-layer sandwich. Topology indicates that structure are grouped according to whether they share the same topology or fold in the core of the domain, that is, if they share the same overall shape and connectivity of the secondary structures in the domain core. Homologous superfamily groups together protein domains which are thought to share a common ancestor and can therefore be described as homologous. Similarities are identified either by high sequence identity or structure comparison using SSAP. Boundaries and assignments for each protein domain are determined using a combination of automated and manual procedures which include computational techniques, empirical and statistical evidence, literature review and expert analysis. Generally if a given protein chain has sufficiently high sequence identity and structural similarity (i.e. $80 \%$ sequence identity, SSAP score $\geq 80$ ) with a chain that has previously been chopped, the domain boundary assignment is performed automatically by inheriting the boundaries from the other chain (ChopClose). Otherwise, the domain boundaries are assigned manually, based on an analysis of results derived from a range of algorithms which include structure based methods [CATHEDRAL, SSAP, DETECTIVE (Swindells, 1995)], PUU (Holm and Sander, 1994), DOMAK (Siddiqui and Barton, 1995), sequence based methods (Profile HMMs) and relevant literature.

\section{How to improve mammary transgene expression?}

We suspect that it is not necessary to consider codon usage optimization when targeting a human gene to express in the animal mammary gland. So we investigated the codon usage pattern between mammary gland and other tissues. Significant differences were found between mammary gland with heart and pancreas tissues both in human and mouse. However, no significant correlation was found between expression levels and codon usage of recombinant human proteins expressed in the milk of transgenic animals. This may indicate that even though a human gene shares a similar codon usage with a mammary gland specific gene, especially milk protein genes, does not guarantee an effective expression in the mammary gland. In contrast, those proteins which share a similar domain with the four caseins are capable of achieving higher expression levels in animal mammary gland. We suppose that the tertiary structure of a recombinant protein adapts to the synthesis and secretion process of milk proteins especially caseins may permit it to be efficiently expressed in animal mammary gland.

In the secretory epithelial cell of mammary gland, milk protein precursors are assembled on the ribosomes of the highly developed rough endoplasmic reticulum (ER). All milk proteins have conserved secretory signal peptide sequences, which lead the growing nascent peptides to insert into the lumen of the ER. The proteins are then transported to the Golgi apparatus. The caseins then gradually intercalate with each other, calcium and phosphate to form a submicellar structures which lead to the formation of casein micelles, finally secreted by reverse pinocytosis (Farrell et al. 2006). Protein folding in the ER is monitored by ER quality control (ERQC) mechanisms. Proteins that pass ERQC criteria traffic to their final destinations through the secretory pathway, whereas non-native and unassembled subunits of multimeric proteins are degraded by the ER-associated degradation (ERAD) pathway (Vembar and Brodsky 2008). Overall, the environment of the ER lumen would be conducive to the proper caseincasein association, which helps them to escape ERAD and move onto the Golgi for processing and secretion. Thus the recombinant proteins as SERPINA1, SERPINC1, SERPING1 and BCHE, which have compact spherical structures composed of mainly alpha beta, 2-lalyer or 3-layer sandwich like domains, presumably form self-association or interact with caseins through the conserved structural elements, and escape the ERAD, and are efficiently transported to the Golgi apparatus to assemble micelles, and ultimately efficiently secreted into milk, lead to a high expression level in the transgenic milk. In contrast, AFP, CAT, FIX, IL2, NGF, and tPA all have a mainly alpha or beta barrel based domain which is quite different from casein (Supplementary Fig. 10). They may not interact with caseins properly and are aggregated to evoke the ERAD, thus fail to traffic to the Golgi apparatus, and ultimate lead to less efficient expression in the milk of transgenic animals. 
Today it is still difficult to exactly predict the expression efficiency of one transgenic animal bioreactor. Because the expression efficiency of mammary transgene relies on a series of complex molecular regulation and cellular process. And it may be animal species dependent. Protein tertiary structure may be an important factor affecting the expression of animal mammary transgene. We doubt this is an absolute factor but, for example, for those proteins failing to secrete into transgenic milk even after transcriptional optimization, we might need to pay more attention to their tertiary structures. We may need to generate a group of elaborately designed gene targeting mice expressing structural distinct proteins under similar transcriptional regulation to verify this hypothesis. Furthermore, if for mammary transgenes encoding proteins that are structurally distinct from caseins such that they may pass through the ER/Golgi-dependent classical secretion pathway inefficiently, raises engineering the non-classical secretary pathway (He et al. 2008a, b; Nickel 2003) as an intriguing option.

Acknowledgments This work was supported by National S\&T Major Project of China (grant no. 2008ZX08006-005).

Open Access This article is distributed under the terms of the Creative Commons Attribution Noncommercial License which permits any noncommercial use, distribution, and reproduction in any medium, provided the original author(s) and source are credited.

\section{References}

Archer JS, Kennan WS, Gould MN, Bremel RD (1994) Human growth hormone (hGH) secretion in milk of goats after direct transfer of the hGH gene into the mammary gland by using replication-defective retrovirus vectors. Proc Natl Acad Sci USA 91:6840-6844. doi:10.1073/pnas. 91.15.6840

Baguisi A, Behboodi E, Melican DT, Pollock JS, Destrempes MM, Cammuso C, Williams JL, Nims SD, Porter CA, Midura P, Palacios MJ, Ayres SL, Denniston RS, Hayes ML, Ziomek CA, Meade HM, Godke RA, Gavin WG, Overstrom EW, Echelard Y (1999) Production of goats by somatic cell nuclear transfer. Nat Biotechnol 17:456-461. doi: $10.1038 / 8632$

Baldassarre H, Hockley DK, Dore M, Brochu E, Hakier B, Zhao X, Bordignon V (2008) Lactation performance of transgenic goats expressing recombinant human butyrylcholinesterase in the milk. Transgenic Res 17:73-84. doi: 10.1007/s11248-007-9137-4

Bijvoet AG, Kroos MA, Pieper FR, Van der Vliet M, De Boer HA, Van der Ploeg AT, Verbeet MP, Reuser AJ (1998) Recombinant human acid alpha-glucosidase: high level production in mouse milk, biochemical characteristics, correction of enzyme deficiency in GSDII KO mice. Hum Mol Genet 7:1815-1824. doi:10.1093/hmg/7.11.1815

Bijvoet AG, Van Hirtum H, Kroos MA, Van de Kamp EH, Schoneveld O, Visser P, Brakenhoff JP, Weggeman M, van Corven EJ, Van der Ploeg AT, Reuser AJ (1999) Human acid alpha-glucosidase from rabbit milk has therapeutic effect in mice with glycogen storage disease type II. Hum Mol Genet 8:2145-2153. doi:10.1093/hmg/ 8.12.2145

Bosze Z, Baranyi M, Whitelaw CB (2008) Producing recombinant human milk proteins in the milk of livestock species. Adv Exp Med Biol 606:357-393

Brem G, Hartl P, Besenfelder U, Wolf E, Zinovieva N, Pfaller R (1994) Expression of synthetic cDNA sequences encoding human insulin-like growth factor-1 (IGF-1) in the mammary gland of transgenic rabbits. Gene 149:351355. doi:10.1016/0378-1119(94)90175-9

Buhler TA, Bruyere T, Went DF, Stranzinger G, Burki K (1990) Rabbit beta-casein promoter directs secretion of human interleukin-2 into the milk of transgenic rabbits. Biotechnology (N Y) 8:140-143. doi:10.1038/nbt0290-140

Butler SP, van Cott K, Subrumanian A, Gwazduaskas FC, Velander WH (1997) Current progress in the production of recombinant human fibrinogen in the milk of transgenic animals. Thromb Haemost 78:537-542

Christa L, Pauloin A, Simon MT, Stinnakre MG, Fontaine ML, Delpal S, Ollivier-Bousquet M, Brechot C, Devinoy E (2000) High expression of the human hepatocarcinomaintestine-pancreas/pancreatic-associated protein (HIP/ PAP) gene in the mammary gland of lactating transgenic mice. Secretion into the milk and purification of the HIP/ PAP lectin. Eur J Biochem 267:1665-1671. doi:10.1046/ j.1432-1327.2000.01159.x

Clark AJ (1998) The mammary gland as a bioreactor: expression, processing, and production of recombinant proteins. J Mammary Gland Biol Neoplasia 3:337-350. doi:10.1023/A:1018723712996

Coulibaly S, Besenfelder U, Fleischmann M, Zinovieva N, Grossmann A, Wozny M, Bartke I, Togel M, Muller M, Brem G (1999) Human nerve growth factor beta (hNGFbeta): mammary gland specific expression and production in transgenic rabbits. FEBS Lett 444:111-116. doi:10. 1016/S0014-5793(98)01728-1

Dittmar KA, Goodenbour JM, Pan T (2006) Tissue-specific differences in human transfer RNA expression. PLoS Genet 2:e221

Dragin S, Chrastinova L, Makarevich A, Chrenek P (2005) Production of recombinant human protein $\mathrm{C}$ in the milk of transgenic rabbits from the F3 generation. Folia Biol (Krakow) 53:129-132. doi:10.3409/173491605775142684

Ebert KM, Selgrath JP, DiTullio P, Denman J, Smith TE, Memon MA, Schindler JE, Monastersky GM, Vitale JA, Gordon K (1991) Transgenic production of a variant of human tissue-type plasminogen activator in goat milk: generation of transgenic goats and analysis of expression. Biotechnology (N Y) 9:835-838. doi:10.1038/nbt0991835

Ebert KM, DiTullio P, Barry CA, Schindler JE, Ayres SL, Smith TE, Pellerin LJ, Meade HM, Denman J, Roberts B (1994) Induction of human tissue plasminogen activator in 
the mammary gland of transgenic goats. Biotechnology (N Y) 12:699-702. doi:10.1038/nbt0794-699

Farrell HM, Malin EL, Brown EM, Qi PX (2006) Casein micelle structure: what can be learned from milk synthesis and structural biology? Curr Opinion Colloid Inter Sci 11:135-147. doi:10.1016/j.cocis.2005.11.005

Gustafsson C, Govindarajan S, Minshull J (2004) Codon bias and heterologous protein expression. Trends Biotechnol 22:346-353. doi:10.1016/j.tibtech.2004.04.006

Han ZS, Li QW, Zhang ZY, Xiao B, Gao DW, Wu SY, Li J, Zhao HW, Jiang ZL, Hu JH (2007) High-level expression of human lactoferrin in the milk of goats by using replication-defective adenoviral vectors. Protein Expr Purif 53:225-231. doi:10.1016/j.pep.2006.11.019

He ZY, Sun XZ, Mei G, Yu SL, Li N (2008a) Nonclassical secretion of human catalase on the surface of $\mathrm{CHO}$ cells is more efficient than classical secretion. Cell Biol Int 32:367-373. doi:10.1016/j.cellbi.2007.12.003

He Z, Yu S, Mei G, Zheng M, Wang M, Dai Y, Tang B, Li N (2008b) Maternally transmitted milk containing recombinant human catalase provides protection against oxidation for mouse offspring during lactation. Free Radic Biol Med 45:1135-1142. doi:10.1016/j.freeradbiomed.2008. 07.019

Holm L, Sander C (1994) Parser for protein folding units. Proteins 19:256-268. doi:10.1002/prot.340190309

Houdebine LM (2000) Transgenic animal bioreactors. Transgenic Res 9:305-320

Houdebine LM (2009) Production of pharmaceutical proteins by transgenic animals. Comp Immunol Microbiol Infect Dis 32:107-121. doi:10.1016/j.cimid.2007.11.005

Hsiao LL, Dangond F, Yoshida T, Hong R, Jensen RV, Misra J, Dillon W, Lee KF, Clark KE, Haverty P, Weng Z, Mutter GL, Frosch MP, Macdonald ME, Milford EL, Crum CP, Bueno R, Pratt RE, Mahadevappa M, Warrington JA, Stephanopoulos G, Stephanopoulos G, Gullans SR (2001) A compendium of gene expression in normal human tissues. Physiol Genomics 7:97-104. doi: 10.1152/physiolgenomics.00040.2001

Huang YJ, Huang Y, Baldassarre H, Wang B, Lazaris A, Leduc M, Bilodeau AS, Bellemare A, Cote M, Herskovits P, Touati M, Turcotte C, Valeanu L, Lemee N, Wilgus H, Begin I, Bhatia B, Rao K, Neveu N, Brochu E, Pierson J, Hockley DK, Cerasoli DM, Lenz DE, Karatzas CN, Langermann S (2007) Recombinant human butyrylcholinesterase from milk of transgenic animals to protect against organophosphate poisoning. Proc Natl Acad Sci USA 104:13603-13608. doi:10.1073/pnas.0702756104

Hyvonen P, Suojala L, Orro T, Haaranen J, Simola O, Rontved C, Pyorala S (2006) Transgenic cows that produce recombinant human lactoferrin in milk are not protected from experimental Escherichia coli intramammary infection. Infect Immun 74:6206-6212. doi:10.1128/IAI.002 38-06

Jensen RG (1995) Handbook of milk composition. Academic press, San Diege

Kim SJ, Sohn BH, Jeong S, Pak KW, Park JS, Park IY, Lee TH, Choi YH, Lee CS, Han YM, Yu DY, Lee KK (1999) High-level expression of human lactoferrin in milk of transgenic mice using genomic lactoferrin sequence. J Biochem 126:320-325
Korhonen VP, Tolvanen M, Hyttinen JM, Uusi-Oukari M, Sinervirta R, Alhonen L, Jauhiainen M, Janne OA, Janne J (1997) Expression of bovine beta-lactoglobulin/human erythropoietin fusion protein in the milk of transgenic mice and rabbits. Eur J Biochem 245:482-489. doi: 10.1111/j.1432-1033.1997.00482.x

Krimpenfort P, Rademakers A, Eyestone W, van der Schans A, van den Broek S, Kooiman P, Kootwijk E, Platenburg G, Pieper F, Strijker R et al. (1991) Generation of transgenic dairy cattle using 'in vitro' embryo production. Biotechnology (N Y) 9:844-847. doi: 10.1038/nbt0991-844

Lee CS, Kim K, Yu DY, Lee KK (1996) An efficient expression of human growth hormone (hGH) in the milk of transgenic mice using rat beta-casein/hGH fusion genes. Appl Biochem Biotechnol 56:211-222

Li L, Shen W, Min L, Dong H, Sun Y, Pan Q (2006) Human lactoferrin transgenic rabbits produced efficiently using dimethylsulfoxide-sperm-mediated gene transfer. Reprod Fertil Dev 18:689-695. doi:10.1071/RD06001

Liang S, Li Y, Be X, Howes S, Liu W (2006) Detecting and profiling tissue-selective genes. Physiol Genomics 26:158-162. doi:10.1152/physiolgenomics.00313.2005

Limonta JM, Castro FO, Martinez R, Puentes P, Ramos B, Aguilar A, Lleonart RL, de la Fuente J (1995) Transgenic rabbits as bioreactors for the production of human growth hormone. J Biotechnol 40:49-58. doi:10.1016/0168-1656 (95)00026-M

Lindsay M, Gil GC, Cadiz A, Velander WH, Zhang C, Van Cott KE (2004) Purification of recombinant DNA-derived factor IX produced in transgenic pig milk and fractionation of active and inactive subpopulations. J Chromatogr A 1026:149-157. doi:10.1016/j.chroma.2003.11.006

Liu Z, Zhao C, Fan B, Dai Y, Zhao Z, Wang L, Zheng M, Feng J, Chen Y, Duan Y, Li N (2004) Variable expression of human lactoferrin gene in mice milk driven by its $90 \mathrm{~KB}$ upstream flanking sequences. Anim Biotechnol 15:21-31. doi:10.1081/ABIO-120029810

Massoud M, Attal J, Thepot D, Pointu H, Stinnakre MG, Theron MC, Lopez C, Houdebine LM (1996) The deleterious effects of human erythropoietin gene driven by the rabbit whey acidic protein gene promoter in transgenic rabbits. Reprod Nutr Dev 36:555-563. doi:10.1051/rnd: 19960511

McKee C, Gibson A, Dalrymple M, Emslie L, Garner I, Cottingham I (1998) Production of biologically active salmon calcitonin in the milk of transgenic rabbits. Nat Biotechnol 16:647-651. doi:10.1038/nbt0798-647

Monaco MH, Gronlund DE, Bleck GT, Hurley WL, Wheeler MB, Donovan SM (2005) Mammary specific transgenic over-expression of insulin-like growth factor-I (IGF-I) increases pig milk IGF-I and IGF binding proteins, with no effect on milk composition or yield. Transgenic Res 14:761-773. doi:10.1007/s11248-005-7219-8

Nickel W (2003) The mystery of nonclassical protein secretion. A current view on cargo proteins and potential export routes. Eur J Biochem 270:2109-2119. doi:10.1046/j. 1432-1033.2003.03577.x

Niemann H, Halter R, Carnwath JW, Herrmann D, Lemme E, Paul D (1999) Expression of human blood clotting factor VIII in the mammary gland of transgenic sheep. Transgenic Res 8:237-247. doi: 10.1023/A:1008999622117 
Paleyanda RK, Velander WH, Lee TK, Scandella DH, Gwazdauskas FC, Knight JW, Hoyer LW, Drohan WN, Lubon H (1997) Transgenic pigs produce functional human factor VIII in milk. Nat Biotechnol 15:971-975. doi: 10.1038/nbt1097-971

Parker MH, Birck-Wilson E, Allard G, Masiello N, Day M, Murphy KP, Paragas V, Silver S, Moody MD (2004) Purification and characterization of a recombinant version of human alpha-fetoprotein expressed in the milk of transgenic goats. Protein Expr Purif 38:177-183. doi: 10.1016/j.pep.2004.07.007

Platenburg GJ, Kootwijk EP, Kooiman PM, Woloshuk SL, Nuijens JH, Krimpenfort PJ, Pieper FR, de Boer HA, Strijker R (1994) Expression of human lactoferrin in milk of transgenic mice. Transgenic Res 3:99-108. doi: 10.1007/BF01974087

Plotkin JB, Robins H, Levine AJ (2004) Tissue-specific codon usage and the expression of human genes. Proc Natl Acad Sci USA 101:12588-12591. doi:10.1073/pnas.040495 7101

Prunkard D, Cottingham I, Garner I, Bruce S, Dalrymple M, Lasser G, Bishop P, Foster D (1996) High-level expression of recombinant human fibrinogen in the milk of transgenic mice. Nat Biotechnol 14:867-871. doi: 10.1038/nbt0796-867

Riego E, Limonta J, Aguilar A, Perez A, de Armas R, Solano R, Ramos B, Castro FO, de la Fuente J (1993) Production of transgenic mice and rabbits that carry and express the human tissue plasminogen activator cDNA under the control of a bovine alpha S1 casein promoter. Theriogenology 39:1173-1185. doi:10.1016/0093-691X(93) 90015-W

Saito-Hisaminato A, Katagiri T, Kakiuchi S, Nakamura T, Tsunoda T, Nakamura Y (2002) Genome-wide profiling of gene expression in 29 normal human tissues with a cDNA microarray. DNA Res 9:35-45. doi:10.1093/ dnares/9.2.35

Salamone D, Baranao L, Santos C, Bussmann L, Artuso J, Werning C, Prync A, Carbonetto C, Dabsys S, Munar C, Salaberry R, Berra G, Berra I, Fernandez N, Papouchado M, Foti M, Judewicz N, Mujica I, Munoz L, Alvarez SF, Gonzalez E, Zimmermann J, Criscuolo M, Melo C (2006) High level expression of bioactive recombinant human growth hormone in the milk of a cloned transgenic cow. J Biotechnol 124:469-472. doi:10.1016/j.jbiotec.2006.01. 005

Sanchez O, Toledo JR, Rodriguez MP, Castro FO (2004) Adenoviral vector mediates high expression levels of human growth hormone in the milk of mice and goats. $\mathrm{J}$ Biotechnol 114:89-97. doi:10.1016/j.jbiotec.2004.06.009

Schnieke AE, Kind AJ, Ritchie WA, Mycock K, Scott AR, Ritchie M, Wilmut I, Colman A, Campbell KH (1997) Human factor IX transgenic sheep produced by transfer of nuclei from transfected fetal fibroblasts. Science 278:2130-2133. doi:10.1126/science.278.5346.2130

Shani M, Barash I, Nathan M, Ricca G, Searfoss GH, Dekel I, Faerman A, Givol D, Hurwitz DR (1992) Expression of human serum albumin in the milk of transgenic mice. Transgenic Res 1:195-208. doi:10.1007/BF02524750

Shyamsundar R, Kim YH, Higgins JP, Montgomery K, Jorden M, Sethuraman A, van de Rijn M, Botstein D, Brown PO,
Pollack JR (2005) A DNA microarray survey of gene expression in normal human tissues. Genome Biol 6:R22. doi:10.1186/gb-2005-6-3-r22

Siddiqui AS, Barton GJ (1995) Continuous and discontinuous domains: an algorithm for the automatic generation of reliable protein domain definitions. Protein Sci 4:872884. doi: $10.1002 /$ pro.5560040507

Simons JP, McClenaghan M, Clark AJ (1987) Alteration of the quality of milk by expression of sheep beta-lactoglobulin in transgenic mice. Nature 328:530-532

Stromqvist M, Tornell J, Edlund M, Edlund A, Johansson T, Lindgren K, Lundberg L, Hansson L (1996) Recombinant human bile salt-stimulated lipase: an example of defective O-glycosylation of a protein produced in milk of transgenic mice. Transgenic Res 5:475-485. doi:10.1007/BF 01980213

Stromqvist M, Houdebine M, Andersson JO, Edlund A, Johansson T, Viglietta C, Puissant C, Hansson L (1997) Recombinant human extracellular superoxide dismutase produced in milk of transgenic rabbits. Transgenic Res 6:271-278. doi:10.1023/A:1018406611380

Swindells MB (1995) A procedure for detecting structural domains in proteins. Protein Sci 4:103-112

Tang B, Yu S, Zheng M, Ding F, Zhao R, Zhao J, Dai Y, Li N (2008) High level expression of a functional human/ mouse chimeric anti-CD20 monoclonal antibody in milk of transgenic mice. Transgenic Res 17:727-732. doi: 10.1007/s11248-007-9162-3

Toledo JR, Sanchez O, Segui RM, Garcia G, Montanez M, Zamora PA, Rodriguez MP, Cremata JA (2006) High expression level of recombinant human erythropoietin in the milk of non-transgenic goats. J Biotechnol 123:225235. doi:10.1016/j.jbiotec.2005.10.019

van Berkel PH, Welling MM, Geerts M, van Veen HA, Ravensbergen B, Salaheddine M, Pauwels EK, Pieper F, Nuijens JH, Nibbering PH (2002) Large scale production of recombinant human lactoferrin in the milk of transgenic cows. Nat Biotechnol 20:484-487. doi:10.1038/nbt 0502-484

Van Cott KE, Lubon H, Gwazdauskas FC, Knight J, Drohan WN, Velander WH (2001) Recombinant human protein C expression in the milk of transgenic pigs and the effect on endogenous milk immunoglobulin and transferrin levels. Transgenic Res 10:43-51. doi:10.1023/A:100896 3817646

Vembar SS, Brodsky JL (2008) One step at a time: endoplasmic reticulum-associated degradation. Nat Rev Mol Cell Biol 9:944-957. doi:10.1038/nrm2546

Wang J, Yang P, Tang B, Sun X, Zhang R, Guo C, Gong G, Liu Y, Li R, Zhang L, Dai Y, Li N (2008) Expression and characterization of bioactive recombinant human alphalactalbumin in the milk of transgenic cloned cows. J Dairy Sci 91:4466-4476. doi:10.3168/jds.2008-1189

Warrington JA, Nair A, Mahadevappa M, Tsyganskaya M (2000) Comparison of human adult and fetal expression and identification of 535 housekeeping/maintenance genes. Physiol Genomics 2:143-147

Whitelaw CB, Archibald AL et al (1991) Targeting expression to the mammary gland: intronic sequences can enhance the efficiency of gene expression in transgenic mice. Transgenic Res 1(1):3-13. doi:10.1007/BF02512991 
Wright G, Carver A, Cottom D, Reeves D, Scott A, Simons P, Wilmut I, Garner I, Colman A (1991) A. High level expression of active human alpha-1-antitrypsin in the milk of transgenic sheep. Biotechnology (N Y) 9:830-834. doi: 10.1038/nbt0991-830

Yang P, Wang J, Gong G, Sun X, Zhang R, Du Z, Liu Y, Li R, Ding F, Tang B, Dai Y, Li N (2008) Cattle mammary bioreactor generated by a novel procedure of transgenic cloning for large-scale production of functional human lactoferrin. PLoS ONE 3:e3453. doi:10.1371/journal. pone.0003453

Yu Z, Meng Q, Yu H, Fan B, Yu S, Fei J, Wang L, Dai Y, Li N (2006) Expression and bioactivity of recombinant human lysozyme in the milk of transgenic mice. J Dairy Sci 89: 2911-2918

Zavadskaia ES, Zakharova ES, Kadulin SG, Kibardin AV, Kiselev SL, Gnuchev NV (2001) Production of recombinant endostatin in milk from transgenic mice. Genetika 37:1207-1212. doi:10.1023/A:1011953312893

Zhang J, Li L, Cai Y, Xu X, Chen J, Wu Y, Yu H, Yu G, Liu S, Zhang A, Chen J, Cheng G (2008) Expression of active recombinant human lactoferrin in the milk of transgenic goats. Protein Expr Purif 57:127-135. doi:10.1016/j.pep. 2007.10.015 